DOI: $10.24143 / 2073-5529-2019-3-150-158$

УДК 664.9.022

\title{
MATHEMATICAL SIMULATION OF KNIFE PROFILE RESISTANCE FORCE DURING FISH CUTTING
}

\author{
O. V. Ageev, V. A. Naumov, Yu. A. Fatykhov \\ Kaliningrad State Technical University, \\ Kaliningrad, Russian Federation
}

\begin{abstract}
The article focuses on studying the fish cutting process and modeling forces of harmful resistance. The fish muscular tissue rheological properties are described by a Maxwell-Thomson model. The conditions of constrained compression of the material across the width and the absence of constrained compression in the direction of movement of the knife are accepted. On the basis of the energy approach, the profile resistance force of the double-edged knife has been interpreted as deformational force of the friction at the macroscopic scale level, provided that the surface of the faces is smooth. The mathematical models for dimensional and dimensionless profile resistance forces of the knife without side edges have been developed. The dependence of the dimensional force on the sharpening angles, knife thickness, rheological properties and cutting speed has been established. The dependence of the dimensionless force on the dimensionless cutting speed and measure of the muscle tissue elasticity has been shown. The profile resistance forces of flat-back knife and double-edged knives have been analyzed. With sharpening angle of back edges $=5^{\circ} ; 10^{\circ}$; $20^{\circ} ; 50^{\circ}$, force maximums are $0.317 ; 0.306 ; 0.288 ; 0.274$, respectively. When the values of instantaneous modulus of elasticity $1.5 \cdot 10^{5} ; 2.0 \cdot 10^{5} ; 2.5 \cdot 10^{5} ; 3.0 \cdot 10^{5} \mathrm{~N} / \mathrm{m}^{2}$, the maximums of the specified force are $0.310 ; 0.411 ; 0.513 ; 0.614 \mathrm{~N}$, respectively. With the values of elasticity $=4 ; 7 ; 11 ; 15$, dimensionless force maximums of flat-back knife are $1.959 ; 3.166 ; 4.774 ; 6.381$ and without side edges $-1.193 ; 1.864 ; 2.764 ; 3.663$, respectively.
\end{abstract}

Key words: fish, cutting, force, resistance, profile, knife, edge, rheology, viscoelasticity.

For citation: Ageev O. V., Naumov V. A., Fatykhov Yu. A. Mathematical simulation of knife profile resistance force during fish cutting. Vestnik of Astrakhan State Technical University. Series: Fishing Industry. 2019;3:150-158. (In Russ.) DOI: 10.24143/2073-5529-2019-3-150-158.

\section{Introduction}

Ensuring resource saving when cutting fish provides for a thorough analysis of the resistance forces. Reduction of harmful resistance force involves the reduction of its components - the profile resistance forces and the friction force.

Mathematical modeling of the food cutting process is a relevant scientific direction and attracts the attention of researchers. An experimental relationship between the resistance force of the fibrous material destruction and the motion speed of the knife has been established [1]. The effect of the blade sharpening angle on the parameters of this process was analyzed [2]. The regularities of high-speed processing of viscoelastic materials in a wide range of speeds: from $0.001 \mathrm{~m} / \mathrm{s}$ to $10 \mathrm{~m} / \mathrm{s}$, have been studied [3, 4]. Finite element modeling of the viscoelastic product destruction has been performed [5]. An approach to determine the optimal geometry of a knife by minimizing the normal component of the resulting resistance (maximizing "sliding" cutting) has been developed $[6,7]$.

However, currently there is no analytical description of the harmful resistance forces acting on the working tool when cutting fish. At the same time, to optimize the geometry of the knife according by the criterion of minimum resistance, mathematical modeling of the forces acting on its faces is required.

\section{Material}

The choice of rheological models of fish muscle tissue has been substantiated. Differential equations of models with their solutions for three different loading conditions have been considered. The results of experimental tests of muscular tissue of scab, mackerel, Atlantic sardinella for direct creep, relaxation and reverse creep are presented. It has been established that the muscle tissue of the fish 
before destruction shows a limited flow under load, relaxes under constant load to an equilibrium state, and is fully restored at full unloading. It is shown that the results of the experimental tests approximately correspond to the three-element Maxwell - Thomson rheological model.

\section{Methods}

The purpose of mathematical modeling is to determine the profile resistance force that occurs when cutting fish with a two-edged knife without side edges.

According to modern concepts of tribology, the profile resistance force is interpreted as the deformation friction force at the macroscopic scale level [8]; Popov, 2017 [9]. At this level, it is necessary to solve the problem of determining the sliding friction force of the stamp (knife as a completely solid smooth body) on the deformable viscoelastic material (cut muscle tissue of the fish). In this case, the roughness of the knife surface is not taken into account, since the macrogeometry of the profile of the cutting working tool is the determining factor.

The task of finding the deformation force of friction when sliding a knife on a viscoelastic material at the macroscopic level (the profile resistance force) is advisable to solve on the basis of an energy approach $[10,11]$. This approach is more general and is based on the determination of energy losses due to the viscoelastic deformation of the material. The energy approach is valid for a stamp of arbitrary shape, which allows it to be applied to knives with different profiles.

\section{Mathematical simulation}

According to the energy approach, when the stamp slides, the energy dissipation in a viscoelastic material occurs due to viscous friction in the Kelvin-Voigt element damper of the Maxwell-Thomson model. The deformation friction force of the stamp when sliding on a viscoelastic base is determined as follows:

$$
F=\int_{a}^{b}\left[g^{\prime}(y) \cdot p(y)\right] d y+\frac{1}{2 E_{0}}\left[p^{2}(b)-p^{2}(a)\right],
$$

where $p(y)$ - the normal contact pressure on the stamp from the material; $g(y)$ - the function that determines the stamp geometry (the shape of the knife profile); $g^{\prime}(y)$ - derivative of the specified function; $a, b$-coordinates along the axis $(0, y)$ of the extreme points of the arbitrary shape stamp. The function $g(y)$ determines the difference between the coordinates of the point of the stamp profile with the coordinate $y$ and the profile point with zero coordinate, so that $g(0)=0$.

Consider the movement in the fish muscle tissue of an elementary knife, shown in Fig. 1. The center of the moving Cartesian coordinate system $O x y$ is at a point.

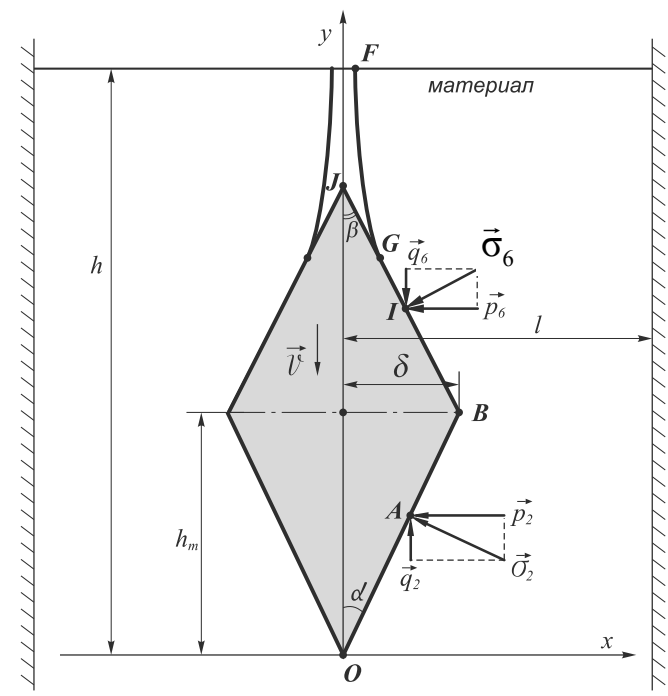

Fig. 1. The scheme of movement of double-edged knife without side edges during fish cutting 
In a quasistatic setting, we believe that at any time the knife is in a state of equilibrium. When cutting, the blade performs a rectilinear uniform motion in the material. The material is in conditions of constrained compression along the axis $O x$, and the cutting is carried out without compressing the material in the direction of knife movement along the axis $O y$ (the height of the material sample is much larger than its width). In Fig. 1 are marked: $\vec{p}_{2}-$ the contact pressure of the horizontal elementary fiber $d y$ at the point $A$, normal to the direction of knife movement; $\vec{q}_{2}$ - the counter material resistance to the movement of the point $A$, due to the deformation of the specified fiber along the axis $O x ; \vec{\sigma}_{2}-$ the contact pressure of the material on the front inclined face at a point $A ; \vec{p}_{6}-$ the normal contact pressure of the horizontal elementary fiber $d y$ at the point $I$ of the back inclined edge of the knife; $\vec{q}_{6}-$ associated contact pressure at the point $I$ of the back inclined edge of the knife; $\vec{\sigma}_{6}$ - the contact pressure of the material on the back inclined edge at a point $I$.

We introduce the following notation: $E_{0}$ - instantaneous modulus of elasticity of fish muscle tissue (Young's modulus); $E_{1}$ - high-elasticity modulus of fish muscle tissue; $\eta$ - the coefficient of dynamic viscosity of the fish muscle tissue; $e_{01}=E_{0} / E_{1}$ - a measure of fish muscle tissue elasticity; $l_{k}-$ blade edge length; $\delta$ - half the thickness of the knife; $\alpha$ - half the angle of sharpening the front edge of the knife; $\beta$ - half the angle of sharpening the back edge of the knife; $t_{\alpha \beta}=\operatorname{tg} \alpha / \operatorname{tg} \beta+; h_{m}$ - height of the inclined front edge; $l$ - half the width of the material in the equilibrium state; $v$ - knife speed; $\xi=\frac{E_{0} \cdot E_{1}}{E_{0}+E_{1}}=\frac{E_{0}}{1+E_{0} / E_{1}} \quad$ (quasistatic modulus of elasticity); $k=-\frac{E_{0}+E_{1}}{\eta \cdot v} ; \mu=1-\exp \left(\frac{k \cdot \delta}{\operatorname{tg} \alpha}\right) ;$ $\chi=\frac{\xi \cdot \eta \cdot v \cdot \mu \cdot \operatorname{tg} \alpha}{E_{1}^{2} \cdot \delta} ; \breve{F}_{1}-$ dimensional profile resistance force; $\widetilde{F}_{1}-$ dimensionless profile resistance force.

The right half of a two-edging (double-edged) knife (Fig. 1) has two extreme contact points: a point $O(0,0)$ and a point $G\left(\delta-\breve{y}_{G} / \operatorname{tg} \beta, \breve{y}_{G}\right)$, as well as one corner point $B\left(\delta, h_{m}\right)$. Thus, in expression (1) $a=0, b=\breve{y}_{G}$. In this regard, the profile resistance force of a two-edging knife according to (1) is determined by the following expression:

$$
\breve{F}_{1}=l_{k}\left(\int_{0}^{\breve{y}_{G}} g^{\prime}(y) \cdot p(y) d y+\frac{1}{2 E_{0}}\left[p^{2}(0)-p^{2}\left(y_{G}\right)\right]\right) .
$$

Let us write the boundary conditions of the knife contact with the material in the following form $p(0)=0 ; p\left(\breve{y}_{G}\right)=0$. Let us represent the integral in expression (2) as the sum of the integrals. Then, taking into account the boundary conditions, the expression (2) has the following form:

$$
\breve{F}_{1}=l_{k}\left(\int_{0}^{h_{m}} g^{\prime}(y) \cdot p_{2}(y) d y+\int_{h_{m}}^{\check{y}_{G}} g^{\prime}(y) \cdot p_{6}(y) d y\right) .
$$

The profile shape of the two-edging knife without side edges determines the type of functions $g(y)$ and $g^{\prime}(y)$ :

$$
g(y)=\left\{\begin{array}{c}
\operatorname{tg} \alpha \cdot y ; y \in\left(0, h_{m}\right) ; \\
-y \cdot \operatorname{tg} \beta ; y \in\left(h_{m}, \breve{y}_{G}\right) ;
\end{array} \quad g^{\prime}(y)=\left\{\begin{array}{c}
\operatorname{tg} \alpha ; y \in\left(0, h_{m}\right) ; \\
-\operatorname{tg} \beta ; y \in\left(h_{m}, \breve{y}_{G}\right) .
\end{array}\right.\right.
$$

Let us substitute into expression (3) the expressions for normal contact pressures $p_{2}(y)$ and $p_{6}(y)$ at the front and back inclined faces and the coordinates $\breve{y}_{G}$ of the extreme contact point $G$, obtained by successively solving the first order differential equation of the Maxwell - Thomson model in regions $O B$ and $B G[12,13]$. We use the formula of Newton - Leibniz and get the expression for the profile resistance force of a two-edging knife without side edges: 


$$
\begin{gathered}
\breve{F}_{1}=\frac{l_{k} \cdot \xi \cdot \operatorname{tg}^{2} \alpha}{l}\left[\frac{h_{m}^{2}}{2}+\frac{\xi \cdot \eta \cdot v}{E_{1}^{2}}\left(h_{m}+\frac{1-\exp \left(k \cdot h_{m}\right)}{k}\right)\right]- \\
-\frac{l_{k} \cdot \xi \cdot \operatorname{tg}^{2} \beta}{l}\left(\frac{h_{\beta} \cdot \chi-\frac{e_{01}}{k}+h_{m}}{k}\left(\exp \left(k\left[\breve{y}_{G}-h_{m}\right]\right)-1\right)+\left(h_{\beta}+\frac{e_{01}}{k}\right)\left(\breve{y}_{G}-h_{m}\right)-\frac{\breve{y}_{G}^{2}-h_{m}{ }^{2}}{2}\right) .
\end{gathered}
$$

Let us introduce the dimensionless knife speed: $\bar{v}=\frac{v}{h_{m}} \cdot \frac{\eta}{\left(E_{0}+E_{1}\right)}$. Then taking into account $\breve{F}_{1}=F_{0} \cdot \bar{F}_{1} ; F_{0}=\left(\delta^{2} \cdot l_{k} \cdot \xi\right) / l ; \xi=E_{0} /\left(1+e_{01}\right) ; \overline{\breve{y}}_{G}=\breve{y}_{G} / h_{m}$ (dimensionless coordinate of a point $G$ ); $t_{\alpha \beta}=\operatorname{tg} \alpha / \operatorname{tg} \beta$, the expression for the dimensionless profile resistance force of a two-edging knife has the following form:

$$
\begin{gathered}
\bar{F}_{1}=\breve{F}_{1} / F_{0}=\left[0,5+\bar{v} \cdot e_{01}(1+(\exp (-1 / \bar{v})-1) \bar{v})\right]- \\
-\frac{1}{t_{\alpha \beta}^{2}}\left\{\left[t_{\alpha \beta} \cdot \chi-e_{01} \cdot \bar{v}-1\right]\left(\exp \left(\frac{1-\bar{y}_{G}}{\bar{v}}\right)-1\right) \bar{v}+\left(t_{\alpha \beta}-e_{01} \cdot \bar{v}\right)\left(\overline{\bar{y}}_{G}-1\right)-\frac{\bar{y}_{G}^{2}-1}{2}\right\} .
\end{gathered}
$$

\section{Results}

Fig. 2-6 show the simulation results of the profile resistance force of a two-edging knife without side edges. The force $F_{1}$ corresponds to a knife with a straight butt, $\hat{F}_{1}-$ a knife with side edges, $\breve{F}_{1}-$ a knife without side edges.

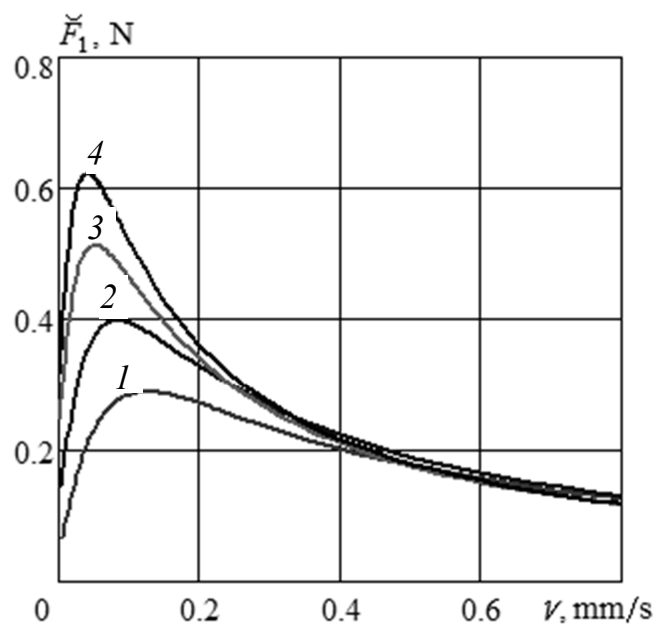

$a$

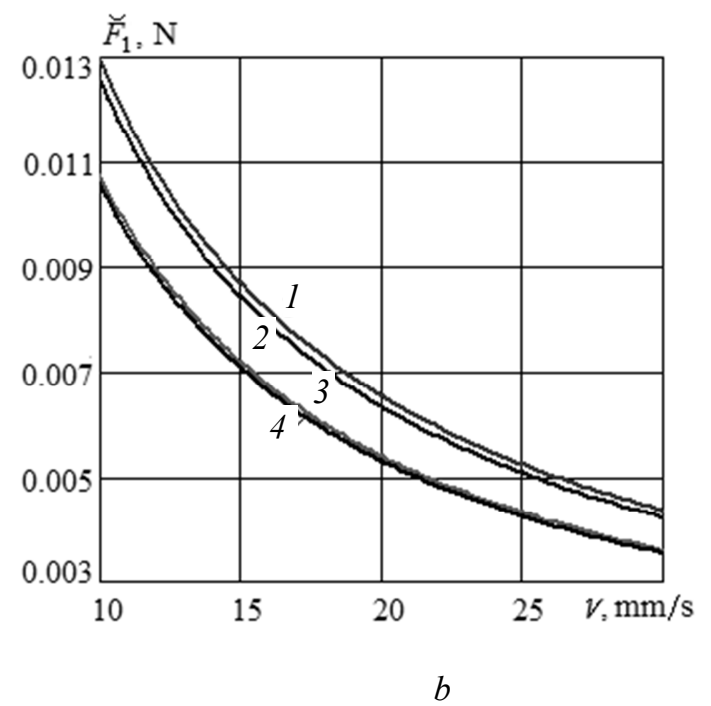

$b$

Fig. 2. Dependence of the profile resistance force on the cutting speed at different rheological properties of the material $\left(\alpha=5^{\circ} ; \beta=15^{\circ} ; \delta=3 \mathrm{~mm} ; l=50 \mathrm{~mm} ; \mathrm{L}=h_{m}=12 \mathrm{~mm}\right)$ :

$a-$ at low speeds; $b-$ at high speeds;

$1-E_{0}=1.5 \cdot 10^{5} \mathrm{~N} / \mathrm{m}^{2}, E_{1}=0.1 \cdot 10^{5} \mathrm{~N} / \mathrm{m}^{2} ; 2-E_{0}=2 \cdot 10^{5} \mathrm{~N} / \mathrm{m}^{2}, E_{1}=0.3 \cdot 10^{5} \mathrm{~N} / \mathrm{m}^{2} ;$

$3-E_{0}=2.5 \cdot 10^{5} \mathrm{~N} / \mathrm{m}^{2}, E_{1}=0.6 \cdot 10^{5} \mathrm{~N} / \mathrm{m}^{2} ; 4-E_{0}=3 \cdot 10^{5} \mathrm{~N} / \mathrm{m}^{2}, E_{1}=0.8 \cdot 10^{5} \mathrm{~N} / \mathrm{m}^{2}$ 

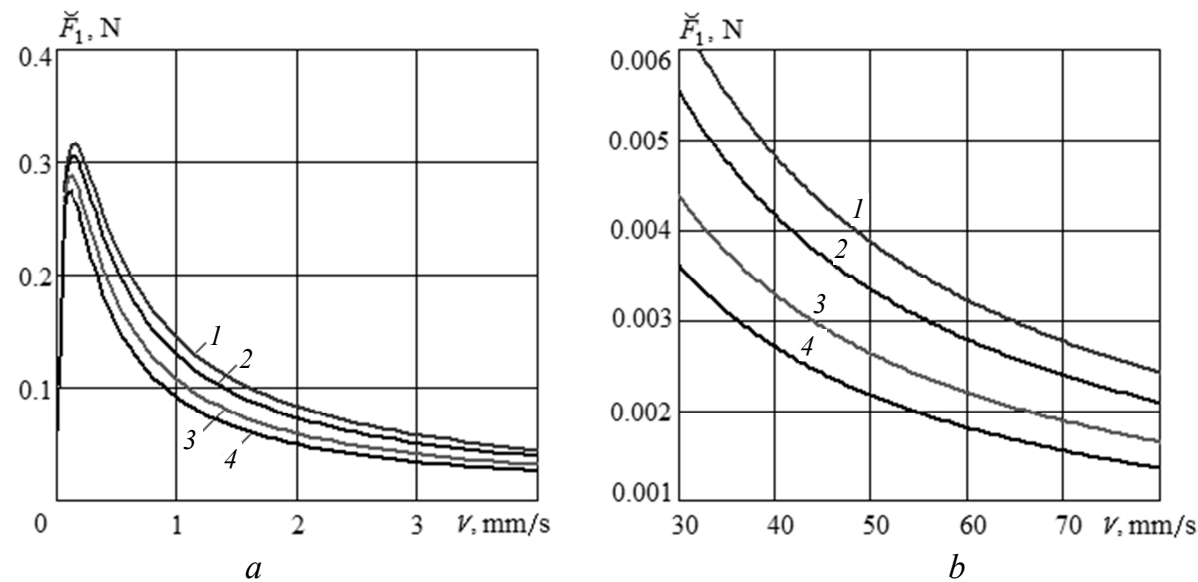

Fig. 3. Dependence of the profile resistance force on the cutting speed at different sharpness half-angle $\beta$ of the back inclined edge: $a-$ at low speeds; $b-$ at high speeds;

$E_{0}=3 \cdot 10^{5} \mathrm{~N} / \mathrm{m}^{2} ; e_{01}=3.75 ; \delta=3 \mathrm{~mm}: 1-\beta=5^{\circ} ; 2-\beta=10^{\circ} ; 3-\beta=20^{\circ} ; 4-\beta=50^{\circ}$
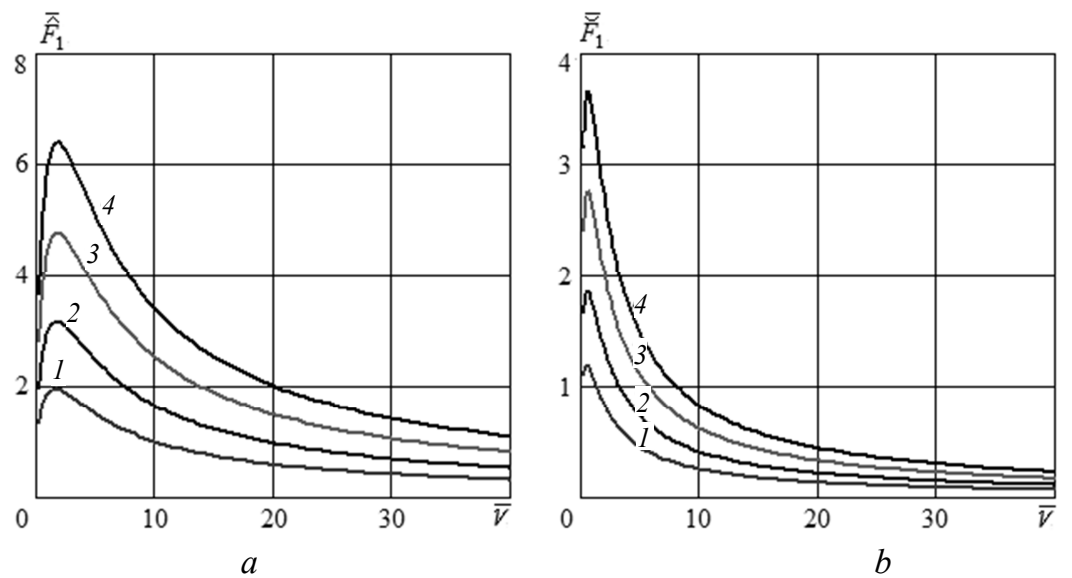

Fig. 4. Dependencies of the dimensionless profile resistance

force of double-edged knife with side edges $(a)$ and knife without side edges $(b)$ on the dimensionless cutting speed at different values of elasticity measure $\left(t_{\alpha \beta}=0.8\right)$ :

$$
1-e_{01}=4 ; 2-e_{01}=7 ; 3-e_{01}=11 ; 4-e_{01}=15
$$
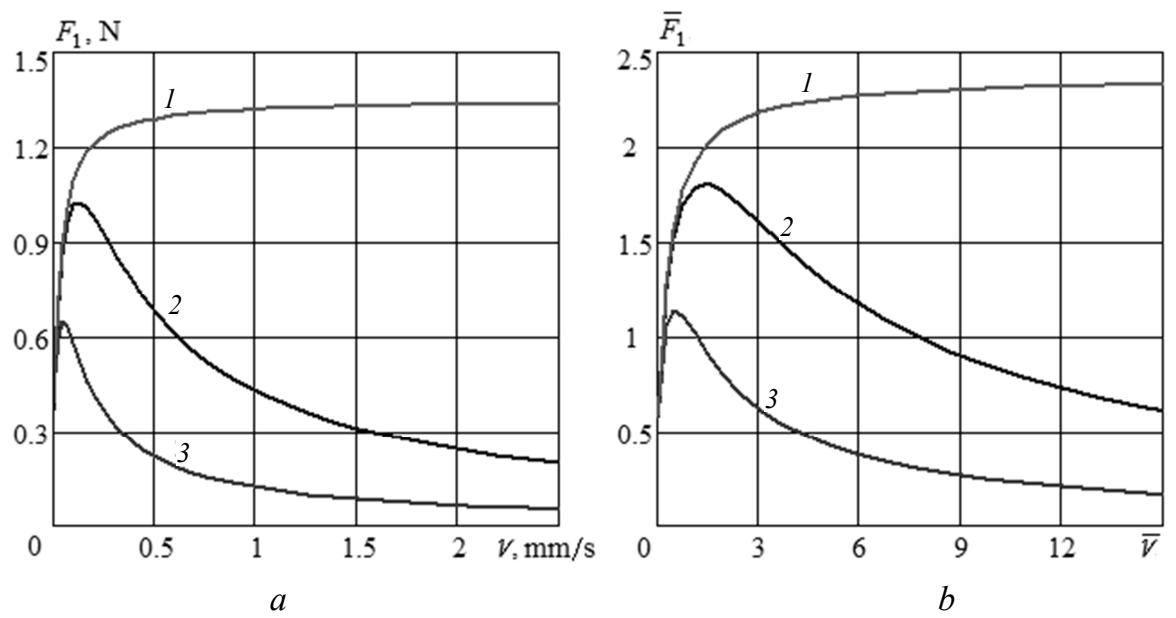

Fig. 5. Dependencies of the dimension $(a)$ and dimensionless $(b)$ profile resistance force on the dimensionless cutting speed:

$$
\begin{gathered}
a-E_{0}=3 \cdot 10^{5} \mathrm{~N} / \mathrm{m}^{2}, E_{1}=0.8 \cdot 10^{5} \mathrm{~N} / \mathrm{m}^{2} ; \eta=1.5 \cdot 10^{7} \mathrm{~N} \cdot \mathrm{s} / \mathrm{m}^{2} ; \alpha=5^{\circ} ; \delta=3 \mathrm{~mm} \\
1-F_{1} ; 2-\hat{F}_{1} ; 3-\breve{F}_{1} ; b-e_{01}=3.75 ; t_{\alpha \beta}=0.8 ; 1-\bar{F}_{1} ; 2-\hat{\hat{F}}_{1} ; 3-\bar{F}_{1}
\end{gathered}
$$



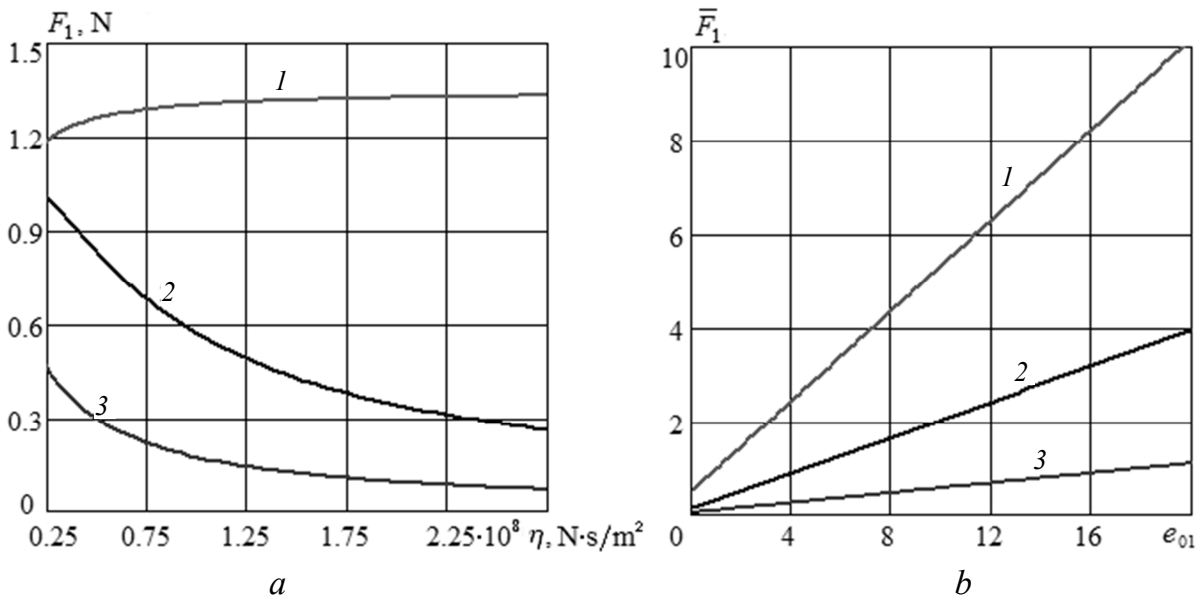

Fig. 6. Dimension $(a)$ and dimensionless $(b)$ profile resistance force:

$a$-dependence of dimension forces on coefficient of dynamic viscosity of the material $(\mathrm{v}=1 \mathrm{~mm} / \mathrm{s})$ :

$$
1-F_{1} ; 2-\hat{F}_{1} ; 3-\breve{F}_{1}
$$

$b$ - dependence of dimensionless forces on elasticity measure $\left(\bar{L}=3 ; \bar{v}=10 ; t_{\alpha \beta}=0.8\right)$ :

$$
1-\bar{F}_{1} ; 2-\overline{\hat{F}}_{1} ; 3-\overline{\bar{F}}_{1}
$$

\section{Discussion of results}

To reduce energy costs for cutting it is necessary to strive to reduce the resistance forces. In this regard, let us analyze the influence of various parameters on the dimensional and dimensionless profile resistance forces of a two-edged (double-edged) knife without side edges (Fig. 1). In this case, the process of reverse creep of the material proceeds without intermediate stress relaxation with constant deformation of the muscle tissue. Fig. 2 shows that with a monotonous increase in the elastic properties of the material, the maximum force increases significantly and is achieved at very low cutting speeds. With a further increase in cutting speed with increased stiffness of muscle tissue, the profile resistance force of the knife decreases. Fig. 3 shows that in the absence of the knife side faces, the influence on the indicated force of the sharpening angle of the back inclined edges is essential. With an increase in the specified angle of sharpening at low cutting speeds, the force maximum decreases, and at high speeds, the force also decreases. At angles of sharpening $5^{\circ} ; 10^{\circ} ; 20^{\circ} ; 50^{\circ}$ the maximums of the considered force are $0.317 ; 0.306 ; 0.288 ; 0.274 \mathrm{~N}$, respectively.

Fig. 4 shows that the absence of stress relaxation with a constant deformation of the material by the side faces leads to a significant decrease in the dimensionless profile resistance force, ceteris paribus. With the values of the elasticity measure $4 ; 7 ; 11 ; 15$ the maximums of the dimensionless force profile resistance force of the knife with the side faces are $1.959 ; 3.166 ; 4.774 ; 6.381$, without side faces $-1.193 ; 1.864 ; 2.764 ; 3.663$, respectively. In general, Fig. $2-4$ show that as the cutting speed increases, the force tends asymptotically to zero.

Fig. 5, 6 illustrate that the greatest profile resistance force occurs in the case of cutting fish with a straight butt knife, and the smallest force corresponds to a two-edging knife without side edges, which, with accepted assumptions, is the most effective tool.

The dependences of dimensional and dimensionless forces on the elastic modulus, elasticity measures and coefficient of dynamic viscosity of a material are monotonic. When the values of the instantaneous modulus of elasticity $3 \cdot 10^{5} \mathrm{~N} / \mathrm{m}^{2}$; lagging modulus of elasticity $0.8 \cdot 10^{5} \mathrm{~N} / \mathrm{m}^{2}$; coefficient of dynamic viscosity $1.5 \cdot 10^{7} \mathrm{~N} \cdot \mathrm{s} / \mathrm{m}^{2}$; the half angle of sharpening the front inclined edges and the half thickness of the knife is $3 \mathrm{~mm}$; then the limit of the profile resistance force of the knife with a straight butt is $1.345 \mathrm{~N}$; the maxima of the resistance forces of the knife with and without side edges are $1.025 \mathrm{~N}$ and $0.646 \mathrm{~N}$, respectively. When the measure of material elasticity is 3.75 and the ratio of tangent angles of sharpening is 0.8 , the limit of the dimensionless profile resistance force of the knife with a straight butt is 2.367 , the maxima of the dimensionless profile resistance force of knives with and without side edges are 1.804 and 1.136 , respectively.

With increasing material viscosity, the profile resistance force of the knife with a straight butt increases and asymptotically tends to the limit value, while the profile resistance forces of the two- 
edged knives decrease and asymptotically tend to zero. At the same time from Fig. 4-6, we see that the minimum dimensional force occures when cutting fish with a knife without side edges. With an increase in the measure of material elasticity, the smallest dimensionless force also corresponds to the specified two-edged knife.

\section{Conclusion}

1. The profile resistance force of the knife essentially depends on the rheological properties of the fish - the elastic modulus and the dynamic viscosity coefficient. With an increase in the rigidity of the raw material, this force is significantly reduced at medium and high cutting speeds.

2. The dependence of the profile resistance force of the knife on the cutting speed is nonmonotonic with a pronounced maximum. With increasing speed, this force asymptotically tends to a zero value, which distinguishes it from the resistance force of a single-edged knife, which, under the same conditions, monotonously increases and asymptotically tends to its limit value.

3. The knife geometry affects the profile resistance force of the knife. Half-angles of sharpening the front and back inclined edges affect the dimensional force, which determines the expediency of setting and solving the problem of optimizing the knife profile by the criterion of the minimum force of harmful resistance. The half thickness of the knife affects the instant-elastic and high-elastic components of the resistance force.

4. The absence of side edges leads to the absence of viscoelastic energy losses during stress relaxation, which leads to a significant reduction in the profile resistance force. This allows us to conclude that for knives with straight edges, ceteris paribus, the lowest energy costs for cutting are provided when cutting with a thin two-edging knife without side edges. This is confirmed by current trends in the development of working tools of filleting machines.

\section{REFERENCES}

1. Dowgiallo A. Cutting force of fibrous materials. Journal of Food Engineering, 2005, no. 66, pp. 57-61.

2. Boisly M., Schuldt S., Kaestner M. G., Schneider Y., Rohm H. Experimental characterisation and numerical modelling of cutting processes in viscoelastic solids. Journal of Food Engineering, 2016, no. 191, pp. 1-9.

3. Schuldt S., Arnold G., Kowalewski J., Schneider Y., Rohm H. Analysis of the sharpness of blades for food cutting. Journal of Food Engineering, 2016, no. 188, pp. 13-20.

4. Schuldt S., Schneider Y., Rohm H. High-speed cutting of foods: Cutting behavior and initial cutting forces. Journal of Food Engineering, 2018, no. 230, pp. 55-62.

5. Pagani M., Perego U. Explicit dynamics simulation of blade cutting of thin elastoplastic shells using "directional" cohesive elements in solid-shell finite element models. Computer methods in applied Mechanics and Engineering, 2015, no. 285, pp. 515-541.

6. Atkins T. Optimum blade configurations for the cutting of soft solids. Engineering Fracture Mechanics, 2006, no. 73, pp. 2523-2531.

7. Atkins T. Prediction of sticking and sliding lengths on the rake faces of tools using cutting forces. International Journal of Mechanical Sciences, 2015, no. 91, pp. 33-45.

8. Goryacheva I. G. Mekhanika frikcionnogo vzaimodejstviya [Mechanics of friction interaction]. Moscow, Nauka Publ., 2001. 478 p.

9. Popov V. L. Contact Mechanics and Friction: Physical Principles and Applications. Berlin, Springer Verlag $\mathrm{GmbH}, 2017.391 \mathrm{p}$.

10. Soldatenkov I. A. K raschetu deformacionnoj sostavlyayushchej sily treniya dlya standartnogo vyazkouprugogo osnovaniya [On calculating deformation component of friction force for a standard viscoelastic base]. Trenie i iznos, 2008, no. 1, vol. 29, pp. 12-21.

11. Soldatenkov I. A. Raschet treniya indentora s fraktal'noj sherohovatost'yu o vyazkouprugoe osnovanie [Calculation of friction indenter with fractal roughness on a viscoelastic base]. Trenie i iznos, 2015, no. 3, vol. 36, pp. 257-262.

12. Ageev O. V., Fatyhov Yu. A., Samojlova N. V. Vybor i identifikaciya reologicheskoj modeli strukturnomekhanicheskih svojstv myshechnoj tkani ryby [Selection and identification of rheological model of structural-mechanical properties of fish muscle tissue]. Izvestiya Kaliningradskogo gosudarstvennogo tekhnicheskogo universiteta, 2018, no. 49, pp. 75-91.

13. Ageev O. V., Naumov V. A., Fatyhov Yu. A., Samojlov N. V. Analiz sootvetstviya reologicheskih modelej strukturno-mekhanicheskim svojstvam ryby [Analysis of rheological models compliance with structural and mechanical properties of fish]. Nauchnyj zhurnal Sankt-Peterburgskogo nacional'nogo issledovatel'skogo universiteta informacionnyh tekhnologij, mekhaniki i optiki. Seriya: Processy i apparaty pishchevyh proizvodstv, 2018, no. 2 (36), pp. 34-43. DOI: 10.17586/2310-1164-2018-11-2-34-43.

The article submitted to the editors 06.04.2019 


\section{INFORMATION ABOUT THE AUTHORS}

Ageev Oleg Viatcheslavovich - Russia, 236022, Kaliningrad; Kaliningrad State Technical University; Candidate of Technical Sciences, Assistant Professor; Assistant Professor of the Department of Food and Refrigeration Machines; oleg.ageev@klgtu.ru.

Naumov Vladimir Arkadievich - Russia, 236022, Kaliningrad; Kaliningrad State Technical University; Doctor of Technical Sciences, Professor; Head of the Department of Water Resources and Water Management; van-old@rambler.ru.

Fatykhov Yuri Adgamovich - Russia, 236022, Kaliningrad; Kaliningrad State Technical University; Doctor of Technical Sciences, Professor; Head of the Department of Food and Refrigeration Machines; yuriy.fatyhov@klgtu.ru.

\section{МАТЕМАТИЧЕСКОЕ МОДЕЛИРОВАНИЕ СИЛЫ СОПРОТИВЛЕНИЯ ПРОФИЛЯ НОЖА ПРИ РЕЗАНИИ РЫБЫ}

\section{О. В. Агеев, В. А. Наумов, Ю. А. Фатыхов}

Калининградский государственный технический университет, Калининград, Российская Федерация

Проведены исследование процесса резания рыбы и моделирование сил вредных сопротивлений. Мышечная ткань рыбы описана реологической моделью Максвелла - Томсона. Приняты условия стесненного сжатия материала по ширине и отсутствия стесненного сжатия по направлению движения ножа. На основе энергетического подхода сила сопротивления формы ножа представлена как деформационная сила трения на макроскопическом масштабном уровне при условии гладкости поверхности граней. Разработаны математические модели для размерной и безразмерной сил сопротивления формы ножа без боковых граней. Установлена зависимость размерной силы от углов заточки, толщины ножа, реологических свойств материала и скорости резания. Прослежена зависимость безразмерной силы от безразмерной скорости резания и меры эластичности мышечной ткани. Выполнен сравнительный анализ сил сопротивления формы ножа с прямым обухом и двухкромочных ножей. При углах заточки задних наклонных граней $5 ; 10 ; 20 ; 50^{\circ}$ максимумы силы составляют 0,317; 0,306; 0,$288 ; 0,274$ Н соответственно. При значениях мгновенного модуля упругости $1,5 \cdot 10^{5} ; 2 \cdot 10^{5}$; $2,5 \cdot 10^{5} ; 3 \cdot 10^{5} \mathrm{H} / \mathrm{M}^{2}$ максимумы силы составляют 0,$310 ; 0,411 ; 0,513 ; 0,614$ Н соответственно. При значениях меры эластичности $4 ; 7 ; 11 ; 15$ максимумы безразмерной силы сопротивления формы ножа с боковыми гранями составляют 1,959; 3,166; 4,774; 6,381; без боковых граней $-1,193 ; 1,864 ; 2,764 ; 3,663$ соответственно.

Ключевые слова: рыба, резание, сила, сопротивление, форма, нож, грань, реология, вязкоупругость.

Для цитирования: Агеев О. В., Наумов В. А., Фатыхов Ю. А. Математическое моделирование силы сопротивления профиля ножа при резании рыбы // Вестник Астраханского государственного технического университета. Серия: Рыбное хозяйство. 2019. № 3. С. 150-158. DOI: $10.24143 / 2073-5529-2019-3-150-158$.

\section{СПИСОК ЛИТЕРАТУРЫ}

1. Dowgiallo A. Cutting force of fibrous materials // Journal of Food Engineering. 2005. N. 66. P. 57-61.

2. Boisly M., Schuldt S., Kaestner M. G., Schneider Y., Rohm H. Experimental characterisation and numerical modelling of cutting processes in viscoelastic solids // Journal of Food Engineering. 2016. N. 191. P. 1-9.

3. Schuldt S., Arnold G., Kowalewski J., Schneider Y., Rohm H. Analysis of the sharpness of blades for food cutting // Journal of Food Engineering. 2016. N. 188. P. 13-20.

4. Schuldt S., Schneider Y., Rohm H. High-speed cutting of foods: Cutting behavior and initial cutting forces // Journal of Food Engineering. 2018. N. 230. P. 55-62. 
5. Pagani M., Perego U. Explicit dynamics simulation of blade cutting of thin elastoplastic shells using "directional" cohesive elements in solid-shell finite element models // Computer methods in applied Mechanics and Engineering. 2015. N. 285. P. 515-541.

6. Atkins T. Optimum blade configurations for the cutting of soft solids // Engineering Fracture Mechanics. 2006. N. 73. P. 2523-2531.

7. Atkins T. Prediction of sticking and sliding lengths on the rake faces of tools using cutting forces // International Journal of Mechanical Sciences. 2015. N. 91. P. 33-45.

8. Горячева И. Г. Механика фрикционного взаимодействия. М.: Наука, 2001. 478 с.

9. Popov V. L. Contact Mechanics and Friction // Physical Principles and Applications. Berlin: Springer Verlag $\mathrm{GmbH}, 2017.391 \mathrm{p}$.

10. Солдатенков И. А. К расчету деформационной составляющей силы трения для стандартного вязкоупругого основания // Трение и износ. 2008. № 1. Т. 29. С. 12-21.

11. Солдатенков И. А. Расчет трения индентора с фрактальной шероховатостью о вязкоупругое основание // Трение и износ. 2015. № 3. Т. 36. С. 257-262.

12. Агеев О. В., Фатыхов Ю. А., Самойлова Н. В. Выбор и идентификация реологической модели структурно-механических свойств мышечной ткани рыбы // Изв. Калинингр. гос. техн. ун-та. 2018. № 49. С. 75-91.

13. Агеев О. В., Наумов В. А., Фатыхов Ю. А., Самойлов Н. В. Анализ соответствия реологических моделей структурно-механическим свойствам рыбы // Науч. журн. Санкт-Петерб. национ. исследоват. ун-та информац. технологий, механики и оптики. Сер.: Процессы и аппараты пищевых производств. 2018. № 2 (36). C. 34-43. DOI: 10.17586/2310-1164-2018-11-2-34-43.

Статья поступила в редакцию 06.04.2019

\section{ИНФОРМАЦИЯ ОБ АВТОРАХ}

Агеев Олег Вячеславович - Россия, 236022, Калининград; Калининградский государственный технический университет; канд. техн. наук, доцент; доцент кафедры пищевых и холодильных машин; oleg.ageev@klgtu.ru.

Наумов Владимир Аркадьевич - Россия, 236022, Калининград; Калининградский государственный технический университет; д-р техн. наук, профессор; зав. кафедрой водных ресурсов и водопользования; van-old@rambler.ru.

Фатыхов Юрий Адгамович - Россия, 236022, Калининград; Калининградский государственный технический университет; д-р техн. наук, профессор; зав. кафедрой пищевых и холодильных машин; yuriy.fatyhov@klgtu.ru.

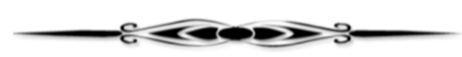

